\title{
A Dutiful Child: The Implications of Article 31 of the African Children's Charter
}

\author{
J Sloth-Nielsen* and BD Mezmur**
}

\begin{abstract}
Each right has a corresponding duty. The African Children's Charter, under article 31 , imposes a range of duties on children. Understandably, it could become contentious when an instrument on the rights and welfare of children expressly imposes duties on them. After setting the platform for discussion by highlighting international experiences and outlining the African concept of human rights, this article critically examines and attempts to clarify the precise meaning, content, conditions of compliance and application of those duties for children. By way of conclusion, it suggests that article 31 represents a valuable addition to the international human rights agenda, and that a purposeful interpretation of its constituent parts reveals that children should be required to play a role at family, community, national and continental levels, in accordance with their age and maturity as they grow up, as part and parcel of their heritage, empowerment and developing citizenship.
\end{abstract}

\section{INTRODUCTION}

The point is often made that each right has a corresponding duty. Hence, the right of an individual implies a duty on the part of society to respect that right. A contrary reading of this conveys the message that every individual, in enjoying their rights, also owes a duty on his or her part towards society. ${ }^{1}$ In the words of Coony, even "[t]he Bible emphasizes duties and responsibilities (not rights). The Ten Commandments are duties ... The

- Professor of Law, University of the Western Cape.

** Doctoral Researcher, Community Law Centre, University of the Western Cape. Email: benyamdawit@yahoo.com.

The authors acknowledge that this work is based upon research supported by the National Research Foundation. This article is based on a paper prepared at the request of the African Committee of Experts on the Rights and Welfare of the Child and presented at its 10th ordinary meeting, Cairo, Egypt (October 2007). The authors would like to thank Albie Sachs J of the Constitutional Court of South Africa and Professor Israel Leeman of the University of the Western Cape for comments made on the draft of this article.

1 This garners support in Rousseau's social contract which presupposed reciprocal rights and responsibilities and "assumed a considerable degree of communal coherence, and the existence of a social ethic of public responsibility, as part of the heritage of feudal society": AR Chapman "Reintegrating rights and responsibilities: Toward a new human rights paradigm" in KW Hunter and TC Mack (eds) International Rights and Responsibility for the Future (1996, Praeger) 3 at 9. 
emphasis on rights to the near exclusion of duties and responsibilities in modern society is a challenge." 2

The Universal Declaration of Human Rights of 1949 (UDHR), including its preamble and all 30 operative articles, has been, and continues to be, a source of inspiration and direction for the standard-setting activities of the UN and the international community at large in the field of human rights. Not only because of its balancing of civil, cultural, economic, political and social rights, but "together with its express reference to duties and an international order for the realization of the rights", ${ }^{3}$ the UDHR occupies a special place in the international human rights discourse. Thus, the UDHR addresses the issue of an individual's responsibilities, as article 29(1) states that "[e]veryone has duties to the community in which alone the free and full development of his personality is possible". However, the UDHR does not codify these duties in detail. There are those who argue that this is a deficiency, ${ }^{4}$ and that there should be a parallel Universal Declaration of Human Responsibilities to fill this perceived gap.

Partly influenced by the UDHR, the preambles of both the International Covenant on Civil and Political Rights (ICCPR $)^{5}$ as well as the Covenant on Economic, Social and Cultural Rights (ICESCR), ${ }^{6}$ both of 1966 , refer to the duties of the individual. The covenants refer to the individual's "duties to other individuals and to the community to which he belongs".?

However, a more specific and detailed range of duties of the individual is the trademark of the African human rights system. The African Charter on Human and Peoples' Rights (the African Charter or ACHPR) has codified a number of duties the individual owes to the community, the state and his/ her parents. ${ }^{8}$ The proponents of this approach argue that, far from duties creating an environment for a gratuitous invasion of rights, duties should

2 M Coony The Australian Achievement, available at: <http:/www.ourcivilisation.com/ cooray/btof/chap226.htm> (last accessed 14 November 2007).

3 G Alfredsson and A Eide "Introduction" in G Alfredsson and A Eide (eds) The Universal Declaration of Human Rights: A Common Standard of Achievement (1999, Martinus Nijhoff) $i$ at xxix.

4 For instance, the Inter Action Council and the 1993 Parliament of the World's Religions. The Inter Action Council's introduction to its Declaration of Human Responsibilities states that it therefore "seeks to bring freedom and responsibility into balance and to promote a move from the freedom of indifference to the freedom of involvement". The 1993 Parliament of the World's Religions Declaration towards a Global Ethic states: "Action in favour of rights and freedoms presumes a consciousness of responsibility and duty, and that therefore both the minds and hearts of women and men must be addressed; that rights without morality cannot long endure, and that there will be no better global order without a global ethic."

5 International Covenant on Civil and Political Rights, General Assembly res 2200A (XXI), 21 UN GAOR supp (no 16) at 52, UN doc A/6316 (1966) 999 UNTS 171, entered into force 23 March 1976.

6 International Covenant on Economic, Social and Cultural Rights, General Assembly res $2200 \mathrm{~A}$ (XXI), 21 UNGAOR supp (no 16) at 49, UN doc A/6316 (1966) 993 UNTS 3, entered into force 3 January 1976.

7 Para 5 of the preambles of both the ICCPR and the ICESCR.

8 See arts 27-29 of the ACHPR. 
be understood as reinforcing rights. ${ }^{9}$ Nonetheless, some have also argued that, although a balance is required between rights and duties, it is not the task of international instruments to deal with them in equal depth. ${ }^{10}$ Concerns are raised at the possible abuse of the language of duties (by governments) to curtail the rights of individuals. ${ }^{11}$ At the extreme, the possibility of governments making the enjoyment of human rights dependent on the fulfilment of duties towards the state is feared as having a suspiciously illiberal ring.

But nowhere else is the language of duties more contentious than in the field of children's rights, in so far as an instrument on the rights and welfare of children expressly imposes a range of duties on them. Such is the case with the African Charter on the Rights and Welfare of the Child (African Children's Charter), ${ }^{12}$ the treaty which constitutes the central theme of this article. In a vein similar to that of the African Charter, the African Children's Charter imposes a range of duties on the child, duties which are owed to his/her parents, the community and the state. ${ }^{13}$ This inclusion of duties of the child under the African Children's Charter has attracted criticism from some scholars. ${ }^{14}$

After introducing the subject matter for discussion, the second part of this article looks at the language of duties/responsibilities of the individual from the perspective of international human rights instruments. The UDHR, the ICCPR, the ICESCR, the Convention on the Rights of the Child $(\mathrm{CRC})^{15}$ and some of the regional treaties are presented for brief analysis. Following this, the third section starts with the premise that, in order to understand the "language of duties" in the African human rights system, one needs to have an informed view of the general concept of human rights in Africa. With this background, the section discusses the language of

9 NB Pityana "The challenge of culture for human rights in Africa" in M Evans and $R$ Murray (eds) The African Charter on Human and Peoples' Rights: The System In Practice 19862000 (2002, Cambridge University Press) 219 at 230.

10 T Opsahl and V Dimitrijevic "Articles 29 and 30" in Alfredsson and Eide (eds) The Universal Declaration of Human Rights, above at note 3, 633 at 637.

11 See, for instance, International Human Rights Policy Taking Duties Seriously: Individual Duties in International Human Rights Law; A Commentary (1999, International Human Rights Policy Council).

12 The African Children's Charter is the first comprehensive regional children's rights treaty specifically dedicated to children in Africa. African Charter on the Rights and Welfare of the Child (1990) OAU doc CAB/LEG/24.9/49.

13 Art 31 of the African Children's Charter.

14 D Olowu "Protecting children's rights in Africa: A critique of the African Charter on the Rights and Welfare of the Child" (2002) 10 The International Joumal of Children's Rights 127; D Chirwa "The merits and demerits of the African Charter on the Rights and Welfare of the Child" (2002) 10 International Journal on Children's Rights 157; A Lloyd "Evolution of the African Charter on the Rights and Welfare of the Child and the African Committee of Experts: Raising the gauntlet" (2002) 10 International Journal of Children's Rights 179; M Gose The African Charter on the Rights and Welfare of the Child (2002, Community Law Centre, University of the Western Cape).

15 United Nations Convention on the Rights of the Child (adopted November 1989 and entered into force September 1990). 
duties under the ACHPR. The article examines the potential meanings and jurisprudential implications of such duties.

The fourth section, which is central to the article, looks at the duties of children under the African Children's Charter. Some of the questions this section attempts to address include: What duties could children possibly have? How could these duties be imposed on children without violating their rights? What standards could these duties be assessed against to ensure their legality? And what are the implications of enforcing these duties? In summary, this part attempts to clarify the precise meaning (as much as possible), content, conditions of compliance and application of those duties for children. A concluding section sums up the article.

\section{THE LANGUAGE OF DUTIES UNDER INTERNATIONAL HUMAN RIGHTS LAW}

As alluded to above, at the international level the UDHR, ICCPR and ICESCR make reference to the duties of the individual. Although largely focused on the individual, the UDHR opens with a deeply moral paragraph stating that "[a]ll human beings are born free and equal in dignity and rights. They are endowed with reason and conscience and should act towards one another in a spirit of brotherhood". ${ }^{16}$ The UDHR states that "[e]veryone has duties to the community in which alone the free and full development of his personality is possible", ${ }^{17}$ and many other human rights instruments adopt similar language. ${ }^{18}$ The reference to duties in article $29(1)$ is adopted in the preambles of the ICCPR and ICESCR: "the individual, having duties to other individuals and to the community to which he belongs, is under a responsibility to strive for the promotion and observance of ... [human] rights". ${ }^{19}$ This is indicative of the fact that the drafters of the two covenants supported the idea expressed in article 29 of the UDHR. There are also a number of declarations that incorporate the concept of "duties": two examples being the Declaration on the Right to Development ${ }^{20}$ and the Declaration on Human Rights Defenders. ${ }^{21}$ However, none of the 41 substantive provisions of the CRC expressly imposes duties on the child. Throughout the CRC, duty bearers seem to be parents and the state.

Although finding an authoritative interpretation of article 29 of the UDHR is no easy task, writers have commented that article 29 should be interpreted in accordance with article 30 of the UDHR: ie in no way to limit

16 Art 1 of the UDHR.

17 Art 29(1) of the UDHR.

18 See, for instance, "The African Charter and the Asian Human Rights Commission, our common humanity: Asian Human Rights Charter - A people's charter", available at: <http://www.ahrchk.net/index.php> (last accessed 4 October 2007).

19 Para 5 of the preambles of both the ICCPR and the ICESCR.

20 General Assembly res 41/128, 4 December 1986.

21 Declaration on the Right and Responsibility of Individuals, Groups and Organs of Society to Promote and Protect Universally Recognized Human Rights and Fundamental Freedoms: General Assembly res 53/144, 8 March 1999. 
the human rights of the individual. ${ }^{22}$ Article 30 of the UDHR proclaims that nothing in the declaration "may be interpreted as implying for any State, group or person any right to engage in any activity or to perform any act aimed at the destruction of any of the rights and freedoms set forth herein". It has been remarked that the travaux preparatoires suggest an interpretation of article 29 based on the terms in paragraph 1 about personal development (because article 29(1) reads that "(e)veryone has duties to the community in which alone the free and full development of his personality is possible"), to the extent of recognizing an implicit right to revolt, of which the preamble speaks openly. ${ }^{23}$

The recognition of duties in the UDHR, ICCPR and ICESCR (international bill of rights) is expanded upon in a number of regional human rights treaties, which indicate the creative possibilities open to local communities to elaborate upon, and particularize, the general duties contained in international instruments. Apart from the African Charter, which is discussed in detail in the next section, both the European and interAmerican human rights systems briefly entrench the duties of the individual.

There is only one reference to duties of the individual under the European Convention on Human Rights. Article 10 of this convention declares, in the context of the right to freedom of expression, that "[t]he exercise of these freedoms, since it carries with it duties and responsibilities, may be subject to such formalities, conditions, restrictions or penalties as are prescribed by law and are necessary in a democratic society...".

In contrast to the European system, more reference is made to duties in the inter-American human rights system. Adopted in the same year as the UDHR, the American Declaration of the Rights and Duties of Man (along with the American Convention on Human Rights) ${ }^{24}$ establishes the interAmerican human rights system. The very title of the American declaration demonstrates that express attention was paid to the duties of private actors. In addition to a special section in the declaration emphasizing various "duties", ${ }^{25}$ the preamble also mentions other more general duties,

22 Opsahl and Dimitrijevic "Articles 29 and 30", above at note 10 at 638 . Art 30 of the UDHR proclaims that nothing in the declaration "may be interpreted as implying for any State, group or person any right to engage in any activity or to perform any act aimed at the destruction of any of the rights and freedoms set forth herein".

23 Opsahl and Dimitrijevic "Articles 29 and 30", above at note 10 at 638 .

24 American Declaration of the Rights and Duties of Man, OAS res XXX, adopted by the Ninth International Conference of American States (1948); reprinted in "Basic documents pertaining to human rights in the inter-American system", OEA/Ser.L.V/ II.82 doc.6 rev.1 at 17 (1992). American Convention on Human Rights, 22 November 1969, 36 OAS TS, reprinted in 6 ILM 673 (American Convention).

25 American Declaration of the Rights and Duties of Man, chapter 2, arts XXIX-XXXVIII. For example, art XXIX declares: "It is the duty of the individual so to conduct himself in relation to others that each and every one may fully form and develop his personality"; art XXX adds duties with respect to family members: "It is the duty of every person to aid, support, educate and protect his minor children, and it is the duty of children to honour their parents always and to aid, support and protect them when they need it". 
declaring: " $[\mathrm{t}]$ he fulfillment of duty by each individual is a prerequisite to the rights of all. Rights and duties are interrelated in every social and political activity of man. While rights exalt individual liberty, duties express the dignity of that liberty".

The American Convention on Human Rights reiterates the general expectation that the convention cannot correctly be interpreted as "permitting any State Party, group, or person to suppress the enjoyment or exercise of the rights and freedoms recognized ... or to restrict them to a greater extent than is provided for herein". ${ }^{26}$ The existence of duties of group and individual actors was thereby recognized, albeit indirectly. Additionally, article $32(1)$ of the American Convention recognizes that "[e]very person has responsibilities to ... mankind", and article 32(2) affirms that "[t]he rights of each person are limited by the rights of others ...".

Although the language of duties has been used both in international and regional treaties, clear and concise analysis of the content of these duties is limited. The literature that exists around these treaties and their provisions on duties is not of much help in establishing their substantive meaning and scope of application, let alone for undertaking any comprehensive comparative analysis. In addition, in comparison to the above treaties, the detailed list of duties that the African Charter entrenches is significant. As a result, it is deserving of, and given, substantial attention below.

\section{THE AFRICAN CONCEPT OF HUMAN RIGHTS, THE AFRICAN CHARTER AND DUTIES OF THE INDIVIDUAL}

In order to understand the "language of duties" in the African human rights system, one needs to have an informed view of the general concept of human rights in Africa. This springs from the recognition that there is an overwhelming body of literature and other evidence that indicates that the emphasis on the group - the idea of communitarianism - is indeed a distinct feature of traditional African culture. ${ }^{27}$ The notion of protection of the individual is a great advance over its absolutist antecedents, but the African concept of human rights highlights that it needs to be balanced by the acknowledgement that the individual is embedded within a community. The importance of placing limits upon human assertiveness at all levels of social organization is overlooked if the emphasis is placed only on the protection of individuals. ${ }^{28}$ Thus the African concept of human rights, both traditional and contemporary, recognizes the importance of the group simultaneously with the significance of the individual. ${ }^{29}$

26 Art 29(a) of the American Convention.

27 See, for instance, EK Quashigah et al Legitimate Governance in Africa: International and Domestic Legal Perspectives (1999, Kluwer Law International) 190-91.

28 RA Falk Human Rights Horizons: The Pursuit of Justice in a Globalizing World (2000, Routledge) 88.

29 See, for instance, Quashigah et al Legitimate Governance in Africa, above at note 27. 
African human rights law refers to the various national, regional and international legal instruments concerning the liberties of the people of Africa. In the main, the regional African human rights system is based on the African Charter. ${ }^{30}$

The African Charter is different from the European and inter-American human rights systems in several respects. ${ }^{31}$ Mutua argues that the most notable contributions of the African Charter are the codification of the three "generations" of rights, including the concept of peoples' rights and the imposition of duties on individuals. ${ }^{32}$ As Heyns succinctly states: "[t]he importance of the group in African tradition is already reflected in the title of the African Charter. Because the group or 'people' is considered to be the basic unit of society, in contrast to the West where the individual plays the predominant role, this document, which has been ratified by almost all African states, is entitled the African Charter on Human and Peoples' Rights." 33 (emphasis added)

This difference between the $\Lambda$ frican Charter and its counterparts could have been influenced by the welcoming address of Leopold Senghor (president of Senegal) in 1979 to the meeting of African experts preparing the draft African Charter in Dakar, Senegal. After referring to the example set by international human rights instruments, he said: "[a]s Africans, we shall neither copy, nor strive for originality, for the sake of originality. We must show imagination and effectiveness. We could get inspiration from our beautiful and positive traditions. Therefore, you must keep constantly in mind our values of civilization and the real needs of Africa." 34 The African Charter's articulation of an individual's duties is a further indication of its attempt to balance cultural relativism with universalism in human rights. ${ }^{35}$

30 The African Charter was adopted in 1981 by the 18th Assembly of Heads of State and Government of the Organization of African Unity (OAU), the official body of African states. It is also known as the Banjul Charter because a final draft was adopted in the capital of the Gambia, Banjul. The charter entered into force on October 1986 upon ratification by a simple majority of member states of the OAU.

31 See generally o Okere "The protection of human rights in Africa and the African Charter on Human and Peoples' Rights: Comparative analysis with the European and American systems" (1984) 6 Human Rights Quarterly 141.

32 See generally M Mutua "The African human rights system: A critical evaluation" (1999), available at: <http://hdr.undp.org/docs/publications/background_papers/ MUTUA.PDF> (last accessed 2 October 2007).

33 C Heyns "Where is the voice of Africa in our constitution" (occasional paper no 8, Centre for Human Rights, University of Pretoria, 1996), available at: <http:/www.chr.up.ac.za/ centre_publications/occ_papers/occ8.html > (last accessed 3 October 2007).

34 Meeting of experts for the preparation of the draft African Charter on Human and Peoples' Rights (28 November - 8 December 1979), OAU doc CAB/LEG/67/3/Rev.1, 5.

35 NJ Udombana "Between promise and performance: Revisiting states' obligations under the African Human Rights Charter" (2004) 40 Stanford Journal of International Law 105 at 111. While the principle of cultural relativity should not be raised to an absolute standard to excuse any and all deviations from international human rights standards, it may be used as a check on radical universalism in very carefully defined circumstances. See RE Howard Human Rights in Commonwealth Africa (1986, Rowman and Littlefield) 17. 
In no uncertain terms, articles $27-29$ of the African Charter provide for a host of duties of the individual. These duties are owed to the family, society, the state and even the international community. For example, article 27 entrenches that "[e]very individual shall have duties towards his family and society, the State and other legally recognized communities and the international community". It further substantiates this duty by providing that "[t]he rights and freedoms of each individual shall be exercised with due regard to the rights of others, collective security, morality and common interest". ${ }^{36}$ In addition, "[e]very individual shall have the duty to respect and consider his fellow beings without discrimination, and to maintain relations aimed at promoting, safeguarding and reinforcing mutual respect and tolerance". 37

A number of other both positive and negative duties of the individual are provided for under article 29 of the African Charter. Under article 29(1), the individual shall also have the duty " $[\mathrm{t}] \mathrm{o}$ preserve the harmonious development of the family and to work for the cohesion and respect of the family; to respect his parents at all times, to maintain them in case of need". Article 29 also lists the duties: "[t]o serve his national community by placing his physical and intellectual abilities at its service"; 38 "[t]o preserve and strengthen social and national solidarity, particularly when the latter is threatened"; 39 "[t]o preserve and strengthen the national independence and the territorial integrity of his country and to contribute to its defence in accordance with the law";40 "[t]o work to the best of his abilities and competence, and to pay taxes imposed by law in the interest of the society"; 41 "[t]o preserve and strengthen positive African cultural values in his relations with other members of the society, in the spirit of tolerance, dialogue and consultation and, in general, to contribute to the promotion of the moral well being of society";42 and "[t]o contribute to the best of his abilities, at all times and at all levels, to the promotion and achievement of African unity".43

As a negative obligation, the individual also has the duty "[n]ot to compromise the security of the State whose national or resident he is". ${ }^{44}$ In the context of negative duties, which require people not to do something, it is correctly argued that:

" $[\mathrm{t}]$ he existence of negative duties illustrate [sic] that the assumption that rights and duties are necessarily antagonistic concepts, is largely unfounded. By enforcing the duty to respect the rights of other persons

\footnotetext{
36 Art $27(2)$ of the ACHPR.

37 Id at art 28.

38 Id at art 29(2).

39 Id at art 29(4).

40 Id at art $29(5)$.

41 Id at art 29(6).

42 Id at art $29(7)$.

43 Id at art 29(8).

44 Id at art 29(3).
} 
against one person, one is in effect protecting the rights of those others. This may be called the secondary protection of human rights, through the enforcement of duties. In fact, the state's duty to respect and protect human rights, which is recognized in the new draft, would also require it to ensure this form of protection." 45

The inclusion of these duties in the African Charter drew the attention of scholars and attracted some level of criticism. ${ }^{46}$ For instance, the more general charge against the imposition of duties on the individual is that they would be construed as legitimizing state power to override individual rights.

In addition, the "family" provisions have been thought to condone and support repressive and retrogressive structures and practices of social and political ordering. This is because the exercise of placing on the individual duties to the family has been read to mean entrenching oppressive family structures which marginalize and exclude women from participation in most spheres outside the home. ${ }^{47}$ The duty to "strengthen positive African values" has been labelled as ambiguous on the face of it; the inability accurately to define the term "positive values", as well as the diversity of those values and cultures across the African continent, has been seen to create problems of interpretation and application. ${ }^{48}$

The duty of the individual to serve his/her national community by placing his/her physical and intellectual capacities at its service ${ }^{49}$ has been attacked as dangerous, as it could justify obstacles to freedom of movement of the nationals of a state. ${ }^{50}$ It is also argued that article 29(6), which requires the individual "to work to the best of his abilities", could be used to impose on the individual the obligation to work, possibly leading to forced labour.

However, these fears and concerns, while sometimes understandable, are often flawed and exaggerated, and as a result can be dismissed. The violation of human rights in Africa has not been anchored in the notion of

45 Heyns "Where is the voice of Africa", above at note 33.

46 However, it is important to note that it is the relationship between peoples' and human rights in the African Charter that has drawn more attention than the language of duties. In fact, there has been little concrete discussion of the notion of individual duties in the context of the African Charter. The only published article devoted solely to the discussion of duties is written by M Mutua "The Banjul Charter and the African cultural fingerprint: An evaluation of the language of duties" (1995) 35 Virginia Joumal of International Law 339. See also NJ Udombana "'Arise, O Compatriots': An analysis of 'duties of the citizen' in the Nigerian Constitution" (2002) 34 Zambia Law Journal 24, discussing the concept of duties in constitutional and human rights law.

47 Mutua "The African human rights system", above at note 32 at 9.

48 Udombana "Between promise and performance", above at note 35.

49 Art 29(1) of the ACHPR.

50 W Benedek 'Peoples' rights and individuals' duties as special features of the African Charter on Human and Peoples' Rights" in P Kunig et al (eds) Regional Protection of Human Rights by International Law: The Emerging African System (1985, Nomos Verlagsgesellschaft) 59 at 89. 
duties; rather, the most enduring causes of human rights abuse in Africa (as elsewhere) are social stratification and the consolidation of political power in the hands of a small ruling class. ${ }^{51} \mathrm{~A}$ progressive construction of the African Charter is said to leave no room for the discriminatory treatment of women. ${ }^{52}$ This argument is reinforced by the adoption and ratification of the Protocol on the Rights of Women in Africa. ${ }^{53}$ The duty to promote African unity has been described, in the recent past, as "an especially critical role given arbitrary balkanization by the colonial powers and the ethnic animosities fostered within and between the imposed states". ${ }^{54}$ With regard to promoting "positive African values", Udombana argues, however, that one plausible interpretation is that the African Charter favours African rights to the extent that they do not collide with universal principles. ${ }^{55}$

According to Ouguergouz, the duty of the individual towards the family, especially when applied to the nuclear family (two spouses and their children), is normally sanctioned by domestic (civil or criminal) law. ${ }^{56}$ The individual's duty to respect his family ${ }^{57}$ (immediate or extended) and to maintain and assist his parents is similar to that which is traditionally placed on the individual by domestic law. ${ }^{58}$

Although there might be a justified concern that the right to movement could be curtailed on the basis of article 29(2) of the African Charter, the danger is negligible, as article $12(2)$ of the same instrument is unequivocal in guaranteeing the individual's right to leave his or her country. ${ }^{59}$ In addition, article 5 of the African Charter does not expressly prohibit compulsory labour. However, the possibility that article 29(6) could legally be used to impose a duty to work is minimal in the face of a number of universal human rights standards that proscribe the practice. ${ }^{60}$

Through the practice of the African Commission (which is the oversight body for the implementation of the African Charter), article 27(2), which reads that "[t]he rights and freedoms of each individual shall be exercised with due regard to the rights of others, collective security, morality and common interest", has become perhaps the most significant provision as

51 Howard Human Rights in Commonwealth Africa, above at note 35.

52 Mutua "The African human rights system", above at note 32 at 9.

53 Protocol to the African Charter on Human and Peoples' Rights on the Rights of Women in Africa (adopted July 2003, entered into force October 2005).

54 Mutua "The Banjul Charter", above at note 46 at 371.

55 Udombana "Between promise and performance", above at note 35 at 111.

56 F Ouguergouz The African Charter on Human and Peoples' Rights: A Comprehensive Agenda for Human Dignity and Sustainable Democracy in Africa (2003, Martinus Nijhoff) at 416.

57 Ouguergouz argues (ibid) that this is only of very limited legal scope and is rather a moral obligation.

58 Ibid.

59 Art 12(2) provides "[e]very individual shall have the right to leave any country including his own and to return to his country. This right may only be subject to restrictions provided for by law for the protection of national security, law and order, public health or morality."

60 For instance, International Labour Organization Convention no 105 Concerning the Abolition of Forced Labour, 25 June 1957. 
regards the individual's duties. ${ }^{61}$ This provision has now, in effect, been given the status of a general limitation clause by the African Commission, according to which "[t]he only legitimate reasons for limitations to the rights and freedoms of the African Charter are found in Article 27(2)".62

It is plausibly argued that "|t|he Commission's use of Article 27(2) as a general limitation clause seems to confirm the view that the concept of 'duties' should not be understood as a sinister way of saying rights should first be earned, or that meeting certain duties is a precondition for enjoying human rights". ${ }^{63}$ Rather, it is said to indicate that the exercise of human rights, which are "natural" or valid in themselves, may be limited by the duties of individuals. ${ }^{64}$

With respect to duties, it has been suggested that the African Commission should clarify which of the duties in the African Charter are moral or legal obligations, and what the scope of their application ought to be. ${ }^{65}$ of course, some of these issues continue to be open for debate. However, as shown above, far from duties creating an environment for a gratuitous invasion of rights, duties should be understood as reinforcing rights. ${ }^{66}$ The acceptance and appreciation of the language of duties by Africans is further reflected by the fact that they are not in short supply if one examines the national constitutions of the different African states ${ }^{67}$ The value of duties is elevated further when one takes into account the fact that, in the modern global environment, the key performers are not necessarily states but nonstate actors. ${ }^{68}$ This is so because, if duties are not imposed on non-state actors, their accountability is very minimal, and leeway is provided for the violation of human rights by private actors. The next section examines whether or not the same, and/or similar, duties imposed on a child could be regarded as legally sound, and as reinforcing rights.

\section{ARTICLE 31 OF THE AFRICAN CHILDREN'S CHARTER ON THE DUTIES OF THE CHILD}

Article 31 of the African Children's Charter entitled "Responsibility of the Child" provides in full that:

61 Vo Nmehielle "Development of the African human rights system in the last decade" (2004) 11/3 Human Rights Brief 7.

62 OAU, African Commission, communications 140/94, 141/94 and 145/95: Constitutional Rights Project $\&$ Others $v$ Nigeria para 41, 13th Annual Activity Report (1999).

63 C Heyns "The African regional human rights system: The African Charter" (2004) 108 Pennsylvania State Law Review 679 at 692-93.

64 In other words, rights precede duties and the recognition of duties is merely another way of signifying the kind of limitations that may be placed on rights: ibid.

65 Mutua "The Banjul Charter", above at note 46.

66 Pityana "The challenge of culture", above at note 9.

67 For example, art $41(\mathrm{k})$ of the Constitution of Ghana recognizes the duty to protect the environment. Likewise, art 33 of the Constitution of Benin recognizes the duty of citizens "to fulfill all of their civic and professional responsibilities". 
"Every child shall have responsibilities towards his family and society, the State and other legally recognized communities and the international community. The child, subject to his age and ability, and such limitations as may be contained in the present Charter, shall have the duty;

(a) to work for the cohesion of the family, to respect his parents, superiors and elders at all times and to assist them in case of need;

(b) to serve his national community by placing his physical and intellectual abilities at its service;

(c) to preserve and strengthen social and national solidarity;

(d) to preserve and strengthen African cultural values in his relations with other members of the society, in the spirit of tolerance, dialogue and consultation and to contribute to the moral well-being of society;

(e) to preserve and strengthen the independence and the integrity of his country;

(f) to contribute to the best of his abilities at all times and at all levels, to the promotion and achievement of African unity."

One can decipher from the above that the preambular paragraph, which introduces the specifics of article 31 , contains within it two internal limitations. First, the duties of the child are subject to his or her age and ability. Secondly, the child's duties are subject to "such limitations as may be contained in the present Charter".

The first qualifier entails an open-ended consideration of the child's evolving capacity and ability, concepts which are now the hallmark of the recognition of children's participation rights. The child's right to participate in matters affecting his or her life constitutes a core principle of the $\mathrm{CRC}$, and has long been regarded as the key to the rights-based philosophy of children's rights that replaced welfarist protectionism, in terms of which children were viewed as objects, rather than subjects, of human rights. "The CRC makes it clear that parental direction and guidance to children must be provided in accordance with the child's evolving capacities. It is through participation that children are empowered to take greater responsibility for the exercise of their own rights as they gain confidence and competence to make informed choices." 69

One of the four rights identified by the Committee on the Rights of the Child, and now the African Committee of Experts on the Rights and Welfare of the Child, as forming the foundation of all the other rights referred to in the CRC - participation - and the concomitant subjectivization of children as independent bearers of human rights, rest on proven theories of child development. The thinking is that the closer a child comes to adulthood, the more weighty his/her role ought to be, as he/she matures. Domestic and national laws also frequently provide, for example, for children's

69 See H Thorgeirsdottir "Article 13: The right to freedom of expression" in A Allen et al (eds) A Commentary on the United Nations Convention on the Rights of the Child (2006, Martinus Nijhoff) 1 at 4. 
independent consent at an age younger than 18 (such as consent to medical treatment, HIV testing or adoption), consistent with article 5 of the CRC on the evolving maturity and development of children, and their ability to understand the implications of decision-making in one or another area of their life.

In much contemporary children's rights literature, participation is narrowly construed as according children the right to express views, and thereafter giving those views due weight in accordance with the children's age and maturity. ${ }^{70}$ However, true participation cannot merely mean having a voice, or a forum for expressing opinions, or an opportunity to have a say independently or through a representative. The very word "participate" - to join in, be part of - indicates physical activity beyond the mere verbal or cerebral. Unlike the CRC provisions, article 31 contemplates a form of active participation in societal and communal life at this practical level, namely in respect of the fulfilment by children of their responsibilities. The age and ability limitation, however, ensures that, as children mature towards adulthood, their participation, via the fulfilment of duties, is commensurate with their evolving status and their physical, mental, emotional and other capacities.

The point is also that children mature into adulthood and do not suddenly, upon attaining the age of 18 years, acquire the capacity and ability to assume adult duties without having had any prior experience of them. Indeed, it must surely be in the children's best interests not to enter the wider world completely unprepared for what may be expected of them. It is, of course, a reflection of the realities of African life that children are, in practice, given the opportunity to participate in the tasks, chores and traditions of adulthood before reaching the age of 18 , so as to learn and develop the skills necessary for later family life. So, for example, girl children may be given, in accordance with their age and capacity at various stages of their middle and teenage years, some duties relevant to the preparation of food, tending and nurturing agricultural produce, or to overseeing small livestock. Older children may be required to assist with the rearing of younger siblings, and assisting with household tasks is common to many of Africa's cultures, societies and groups, across rural and urban settings. These are seen as part and parcel of growing up: learning to assume responsibility; acquiring domestic and other skills; and preparing for life itself.

However, as mentioned at the outset, the fact that duties are subject to a limitation (the child's age and ability) clearly distinguishes the responsibilities of the child from harmful or hazardous labour which is not appropriate for their development or which interferes with their educa-

70 This is no doubt due to the express formulation of art 12(1) of the CRC, which states that "States Parties shall assure to the child who is capable of forming his or her own views the right to express those views freely in all matters affecting the child, the views of the child being given due weight in accordance with the age and maturity of the child". 
tion. Indeed, the caution that article 31 opens the way to exploitation of children within the family ${ }^{71}$ is misplaced: a correct reading views age- and ability-appropriate duties as a positive way to involve children in the daily life of the household and to enable them gradually to equip themselves for life as adults. Nor is it true that the child is prematurely subject to adult responsibilities, thus depriving him or her of the freedoms of childhood, as the limitation inherent in the preambular phrase makes it all too clear that children's responsibilities are to be commensurate with their age and stage of development. ${ }^{72}$

The second qualifier contained in article 31 of the African Children's Charter clearly subjects the duties of the child to the general clauses, as well as the specific protections, contained elsewhere in the African Children's Charter's provisions. Having regard to the African Children's Charter provisions protecting children from abuse, neglect and sexual exploitation, it is untrue to suggest that the duty of a child to respect elders (for example) can lead to the perpetuation of sexual abuse within the family, ${ }^{73}$ in that children would be duty bound to obey even commands which violate their rights. Nor is it fair to depict the "duty to respect superiors" as justification for the recruitment of child soldiers by adults, as this is a clear contravention of the charter, the normative provisions of which take precedence over the duties provided for in article 31 .

Finally, in understanding the overarching limitations in article 31, the three general principles, not detailed in this section (the best interests of the child, non-discrimination and the right to life survival and development) must remain at the forefront. The pervading effect of these principles is elaborated upon below in the discussion of the specific duties contained in article 31.

\section{The duty of the child to work for the cohesion of the family, to respect his/her parents, superiors and elders at all times and assist them in case of need}

This duty comprises several elements, some of which are interlinked, whilst others can be regarded as discrete. The constituent elements will be expounded in turn.

71 See G Van Bueren The International Law on the Rights of the Child (1995, Martinus Nijhoff) at 76. See also W Ncube "Recognition and monitoring of children's rights in Africa: Challenges and prospects" in E Verhellen (ed) Children's Rights (1997, Children's Rights Centre, University of Ghent, Belgium) 609 at 613 for a similar sentiment.

72 GS Kamchedzera "The complementarity of the Convention on the Rights of the Child and the African Charter on the Rights and Welfare of the Child" in E Verhellen (ed) Children's Rights (1998, Children's Rights Centre, University of Ghent, Belgium) 549 at 563.

73 See, for instance, P Parkinson "Family law and parent-child contact: Assessing the risk of sexual abuse" (1999) 23 Melboume University Law Review 345. 


\title{
The cohesion of the family
}

The duty towards the family is supplemented and reinforced by articles 18 and 19 of the African Children's Charter. Article 18 establishes the family as the "natural unit and basis of society" and provides further that, as such, the family is entitled to "the protection and support" of the state for its establishment and development. That the concept of family is broad, encompassing more than just parents, is obvious from a reading of article $18(2)$, which refers specifically, and more narrowly, to "spouses", in the context of equality of rights, responsibilities towards their children and possible dissolution of a union. Thus "family" cohesion, as articulated in the first part of article 31(a), must refer to siblings and to members of the extended family, such as grandparents, uncles, aunts, cousins and so forth. As Mutua points out:

\begin{abstract}
"At the root were structures of social and political organization, informed by gender and age, which served to enhance solidarity and ensure the existence of the community intu perpetuity. The Kikuyu of Kenya, for example, achieved a two-tiered form of community organization: at the base was the family group composed of blood relatives, namely a man and his wife or wives, their children, and grand-children, and often great grand-children; the second tier consisted of the clan, a combination of several family groups bearing the same name and believed to have descended from one ancestor". ${ }^{74}$
\end{abstract}

The duty to work towards the cohesion of the family is underpinned by the centrality of the extended family in African custom and practice. The extended family is indeed the glue binding social, economic and political life in African tradition. As Mutua continues, "relationships, rights, and obligations flowed from these organizational structures, giving the community cohesion and viability". ${ }^{75}$ Hence, most individual duties, for adults and children alike, attached at the family and kinship levels, and were usually identifiable through naming: an aunt was expected to act like a mother, an uncle like a father. This is the basis of the saying, found in many African cultures, that it takes a whole village to raise a child. ${ }^{76}$ Ncube is of the view that the African Children's Charter lays greater stress (than the $\mathrm{CRC}$ ) on the role of the family and seems to view it as a centre for the production, processing, development and defence of African traditional and "cultural values ... the African conceptions of children's rights recognize that the family constructs and becomes guardian of society's cultural values and norms...".,77

In this regard, the word "cohesion" assumes some importance. ${ }^{78}$ The nature of the duty envisaged by article 31 (a) is not to work for (a crude and

74 Mutua "The Banjul Charter", above at note 46 at 361.

75 Ibid.

76 Ibid.

77 Ncube "Recognition and monitoring", above at note 71 at 612 .

78 Kamchedzera "The complementarity", above at note 72 , points out that African cultures and traditions, though varying from area to area, are generally unique in that they are traditionally partly premised on social cohesion and communalism. 
mischievous rendition of the scope of the obligation) the family. Rather, the objective of the child's efforts is the cohesion or unity of his kinship circle, an entirely laudable objective even in western terms. The underlying idea is the prevention of the atomization of individuals into socially unviable, unconnected and ultimately disintegrated ${ }^{79}$ structures: the polar opposite of the African Children's Charter's underlining of the family as the natural unit and basis of society.

The question may be posed whether the duty to work for the cohesion of the family is merely a moral duty which is legally unenforceable, or whether it can be construed properly as a legal duty. ${ }^{80}$ Mutua guides us to the understanding that, whilst, in western terms, the duty might be regarded as of moral value only, viewed from the perspective of African kinship structures (even in modernizing or modernized parts of the continent), duties are to be regarded essentially as "rights which each kinship member customarily possesses, and duties which each kinship member has toward his kin...".81 Expressed differently, the right of one kinship member is the duty of another, and the duty of the other kinship member is the right of the former. Sudarkasa and Cobbah thematically group the principles maintaining the kinship system around respect, restraint, responsibility and reciprocity. In a very real sense, "entitlements and obligations form the very basis of the kinship system". 82 There is no denying that the "family" and kinship networks occupy a special place in African philosophy, culture and jurisprudence. As expressed recently by chief justice Pius Langa of the South African Constitutional Court, "[t]he notion that we are not islands unto ourselves is central to the understanding of the individual in African thought. This is often expressed in the phrase umuntu mgumuntu ngabantu which emphasizes communality and the interdependence of the members of the community and that every individual is an extension of others". 83

Hence the duty towards the family is clearly more than a moral one, given that it is the family structure and allocation of roles that define and institutionalize social organization and political life. ${ }^{84}$

79 The word "disintegrated" is the antonym of "cohesive".

80 See Gose The African Charter, above at note 14 at 40-41, for an overview of this debate and his conclusion that the "stated duty of the child is of a merely persuasive nature and can hardly be enforced by legal means".

81 J Cobbah "African values and the human rights debate: An African perspective" (1987) 9 Human Rights Quarterly 309 at 321.

82 Ibid.

83 MEC for Education: Kwazulu-Natal and 3 Others $v$ Navaneethum Pillay and 3 others case no CCT51/06 (Constitutional Court), October 2007 at para 53.

84 The notion that the child's duty to work for the cohesion of the family can be considered as being legally enforceable is supported by developments in international human rights law. No longer can the claim be made that rights are enforceable only against states, as international human rights law has moved towards holding individuals, corporations and other private actors accountable. 
Moving to the consideration of the child's duties within the context of the immediate family, article 19(1) of the African Children's Charter enshrines the child's rights to parental care and protection, and also encapsulates the principle that separation of a child from his or her parents should not occur against the child's will, save where this is in the best interests of the child. This can be regarded as the corollary of the child's duty provided for in article 31(a): the child's duty towards his family and parents does not exist in the abstract, but is linked to the duties of parents, and others who are responsible for the child, to raise that child to adulthood to the best of their abilities and capacities.

The reciprocal nature of the duties and responsibilities between parent and child in the family context is further evident from article $20,{ }^{85}$ which provides for the duty of care-givers to carry out the tasks associated with a child's upbringing and development, provided that the child's best interests are central to the child-rearing endeavour. Even parental discipline is subject to limitation: it must be "administered with humanity" and "in a manner consistent with the inherent dignity of the child". ${ }^{86}$ The reciprocity of obligations imposed upon children and parents as bearers of rights and responsibilities supports the view that the duties of a child are no less legal in nature than those imposed by the African Children's Charter upon parents. ${ }^{87}$

Finally, Mutua points out that "unlike the West, kinship terminologies in Africa relate to actual duties and obligations borne by members. Furthermore, the terminologies are more encompassing: aunts and mothers, for example, have similar roles within the kinship unit, regardless of biological parentage. The same is true of uncles and older cousins" 88 (emphasis added). This too underlines the legal character of this obligation.

The duty to respect his parents, elders and superiors at all times

A jaundiced reading of this duty would subject children to unquestioning obedience in the face of repressive and authoritarian kinship and clan structures. Van Bueren, for example, complains that the responsibility is

85 The authors therefore cannot agree with Chirwa's assertion that "as regards the duties of children ... these seem not to be correlative of any rights stipulated in the Charter ...". See Chirwa "The merits and demerits", above at note 14 at 169.

86 Art 20(1)(c) of the African Children's Charter.

87 Raoul Intudi points out that, in pre-colonial African societies, children were prized as an asset to the family and all family members were responsible for the protection of children. He notes further the positive consequence inherent in providing for children's duties towards their families, in that the child is not merely an object upon whom protection and welfare is bestowed, but an actor, a subject, upon whom the responsibility to promote the overall well-being of the family unit is placed. See generally $R$ Intudi "The application of the International Convention on the Rights of the Child in Africa: When the law is tested by reality" in A Alen et al (eds) The UN Children's Rights Convention: Theory Meets Practice (2007, Intersentia) 23. 
too "unquestioning and general", ${ }^{89}$ leading Gose to characterize the phrase as constituting a duty of obedience. ${ }^{90}$ Even Chirwa, an Africanist if ever there was one, is mildly discouraging about this particular duty, arguing that it "may undermine the child's right to participate in decision making in matters affecting the child in particular and in other matters in general". ${ }^{91}$ Ncube is cautious in his assessment, citing the fear that the duty to respect parents could easily be relied upon to curtail children's rights to freedom of expression, privacy and participation in decision-making. ${ }^{92}$

These views, we would argue, are hardly a fair interpretation, and somewhat misconstrue the positive values that the provision seeks to promote. Further, as mentioned above, the duties in article $\mathbf{3 1}$ are expressly subject to the limitation of rights contained elsewhere in the African Children's Charter; hence tyrannical and despotic parental or elder practices are impermissible. Even more telling, the respect due by children is also subject to respect for their participation rights (article 4), the corollary of which is the parental duty to accord due weight to children's views in accordance with their evolving age and capacity. Thus the African Children's Charter is clear that the protection of the rights and welfare of the child involves duties on everyone (preamble), and this should surely include children as beneficiaries of the care and protection bestowed upon them through the various provisions of the African Children's Charter.

Kenyatta writes that "early and late, by rules of conduct in individual instances, by the sentiment of the group in which he lives, by rewards and punishments and fears of ceremonial uncleanness, the younger generation learns the respect and obedience due to parents. The older generation do likewise". ${ }^{93}$ This matrix of group solidarity revolves around respect, based on: seniority in age; restraint, or the balancing of individual rights with the requirements of the group; responsibility, which requires commitment to work with and help others in return for security; and reciprocity, through which generous acts are returned. ${ }^{94}$ This basic philosophy is supported by Mutua, citing the concept of ujamaa, the Kiswahili concept for kinship, which was based on three principles: (i) respect, where each family member recognizes the place and rights of others within the family; (ii) common ownership of property, that all must have the same basic necessities; and (iii) obligation to work, that every family member has the right to eat and to shelter but also the obligation to work.

The duty to respect parents, elders and superiors is exactly the kind of positive tradition that the African Children's Charter identifies as constituting an asset in the upbringing of African children. It does not

89 Van Bueren The Intermational Law on the Rights of the Child, above at note 71 at 76.

90 Ibid. See also Gose "The African Charter", above at note 14 at 40.

91 Chirwa "The merits and demerits", above at note 14 at 169.

92 Ncube "Recognition and monitoring", above at note 71 at 612.

93 Mutua "The Banjul Charter", above at note 46 at 363, citing J Kenyatta Facing Mount Kenya (1953, Secker and Warburg) 1 at 115.

94 Cobbah "African values and the human rights debate", above at note 81 at 322. 
entail docility, nor unquestioning subservience. It encapsulates the widely shared value that age brings with it wisdom, knowledge and experience, and that this requires that seniors be given due credit. In the words of Justice Sachs, "[t] he choice is not between total subordination to elders on the one hand, and absolute autonomy leading to disrespect on the other, but a harmonization of traditional respect for elders with enjoyment of the freedoms and right to development set out in the other provisions of the Charter". 95

The opposite of the "duty to respect" is a "licence to disrespect" and surely, seen this way, the formulation of the African Children's Charter drives home the point that the intention of the drafters was not to silence children, but rather to celebrate the positive aspects of African child-rearing practices in nurturing a respectful society.

The duty to assist ... in case of need

Few could argue that children have an obligation to assist their families, to the extent of their capacity to do so, in times of need. Mutua puts it in strong terms, albeit that his discussion revolves around the African Charter on Human and Peoples' Rights: "Parents, for example, are owed a duty of respect and maintenance by their children. Crippling economic problems do not allow African states to contemplate some of the programs of the welfare state. The care of the aged and needy falls squarely on family and community members. This requirement - a necessity today - has its roots in the past: it was unthinkable to abandon a parent or relative in need". ${ }^{96}$

Nor is assistance limited to economic or material assistance in the actual wording of the African Children's Charter: it should include emotional and psycho-social support and mention has been made of the duty to assist sick family members, particularly apt in the era of the HIV pandemic. ${ }^{97}$ Gose makes an important point in this regard: this duty does not render children "substitute adults in their actions", but rather they support adults in fulfilling their duties towards the family and in coping with their functions. ${ }^{98}$ He notes that such interpretation is fully compatible with the other provisions that the African Children's Charter enshrines.

Assistance given by children to their families is a familiar concept in municipal legal systems. In Roman-Dutch law, which informed the legal systems of much of southern Africa, ${ }^{99}$ a duty of support rests upon children towards their parents, a duty which persists into adulthood, when parents grow old and unable to support themselves. In customary law, the duty of support is particularly well elaborated and, although customary law is not static and evolves over time in different contexts, modern day perversions,

95 A Sachs, justice of the Constitutional Court of South Africa, in an e-mail comment dated 13 November 2007 (copy on file with authors).

96 Mutua "The Banjul Charter", above at note 46 at 369.

97 Gose The African Charter, above at note 14 at 41 .

98 Ibid.

99 South Africa, Namibia, Lesotho, Zimbabwe, Swaziland and Botswana. 
such as dispossession and property grabbing or abandoning the sick and elderly, are not true reflections of the principle of communitarianism that is the hallmark of the African ethic.

\section{The duty of the child to serve his national community by placing his physical and intellectual abilities at its service}

International and regional human rights law does not prohibit children from ever engaging in any kind of work. The same is true of the African Children's Charter. Article 15(1) of the charter protects every child "... from all forms of economic exploitation and from performing any work that is likely to be hazardous or to interfere with the child's physical, mental, spiritual, moral, or social development" (emphasis added). When activists speak of abolishing child labour, they are talking about protecting children from harm. In an implied support of the duty of the child to serve his national community by placing his physical and intellectual abilities at its service, Human Rights Watch observes that "[i]n some cases, a child's work can be helpful to him or her and to the family; working and earning can be a positive experience in a child's growing up. This depends largely on the age of the child, the conditions in which the child works, and whether work prevents the child from going to school". ${ }^{100}$

Therefore, a clear distinction needs to be made between child work, on the one hand, with which the African Children's Charter does not have a problem, and child labour and its worst forms (including the use of children as soldiers), on the other, where a policy of "zero tolerance" is advocated. The kind of work envisaged by the African Children's Charter - by imposing a duty on the child to serve his/her national community by placing his or her physical and intellectual abilities at its service - is the nonharmful child "labour", which is often part-time and does not preclude educational opportunities.

Children's involvement in the community, as a duty, could take different forms. The work for his/her community, which reflects the concept of "national service" for example, could utilize traditional notions in addressing famine, public works and community self-help projects. ${ }^{101}$ It could also relate to the protection of the environment by the child. In fact, some domestic laws in Africa, for example the Constitution of Ghana, place a duty on everyone to look after the environment. ${ }^{102}$ Thus, for instance, the child could take part in environment conserving activities, such as planting trees. In fact, article 11(2)(g) of the African Children's Charter, on "the aims of education", indicates that "[t]he education of the child shall be directed to the development of respect for the environment and natural resources". This duty of the child could therefore be looked upon as reinforcing the

100 Human Rights Watch Child Labour available at: <http://hrw.org/children/labor.htm> (last accessed 3 October 2007).

101 Mutua "The Banjul Charter", above at note 46 at 375.

102 Constitution of Ghana, art 41(k). 
right that a child has to education which is directed, inter alia, to the development of respect for the environment.

Central to the duty of the child to serve his/her community should also be the valuable contribution that it makes to each individual child's personal growth and cognitive development, which could be labelled as one of the objectives of the African Children's Charter. Such service can also be beneficial to children by giving them an income, a sense of accomplishment, and useful work-related and social skills that will be of benefit to them in their future lives.

The CRC declares that the "child should be fully prepared to live an individual life in society, and be brought up in the spirit of the ideals proclaimed in the Charter of the United Nations, and in particular in the spirit of peace, dignity, tolerance, freedom, equality and solidarity". ${ }^{103} \mathrm{~A}$ similar message is contained in the African Children's Charter. ${ }^{104}$ In other words, children must be raised in the consciousness that their energy and talents should also be devoted to the service of others, as stated in the 1959 UN Declaration of the Rights of the Child. ${ }^{105}$

Nonetheless, under the guise of the duty of the child to serve his national community, states and communities cannot impose or leave a gap for child labour. On the contrary, according to the charter, states parties are required to control and fight against child labour, through laws which provide for compulsory full-time education until a certain age ${ }^{106}$ and a minimum age for employment. ${ }^{107}$ In addition, as argued above in the context of the ACHPR, the duty of the child to serve his national community can neither be deployed to curtail the right of freedom of movement of the child nor be read to impose a blanket obligation to work. As a matter of fact, any construction of the duty which goes against the best interests of the child principle, and other provisions of the African Children's Charter, cannot be accommodated.

Mention must also be made of the laudable characteristic of article 31(b), in that it recognizes not only the physical, but also the intellectual capacity of the child to serve his national community. This is indicative of a childcentred approach, which sees children as capable of developing their minds in society with others and to grow into citizens participating in public life, and not merely to be mindless consumers. Clearly, it is through civic participation that children are empowered to take greater responsibility for the exercise of their own rights, as they gain confidence and competence to make informed choices and contribute to community debates. ${ }^{108}$

103 Para 7 of the preamble to the CRC.

104 Paras 5 and 6 of the African Children's Charter.

105 Thorgeirsdottir Article 13, above at note 69 at 2 .

106 See art 11 of the African Children's Charter.

107 See art 15 of the African Children's Charter

108 G Lansdown Promoting Children's Participation in Democratic Decision-Making (February 2001, Innocenti Insight, UNICEF) at 6. 


\section{The duty of the child to preserve and strengthen social and national solidarity}

Although the notion of a "nation state"109 is fast disappearing in Africa (if it ever existed at all), social and national solidarity plays a major role in the day to day functioning of communities and the state. The concept of $u b u n t u$ is central to African societies and nations: a metaphor which emphasizes communality and the interdependence of the members of the community, and that every individual is an extension of others. It describes group solidarity, especially where such group solidarity is central to the survival of communities with scarce resources. The consciousness of separateness, otherness, and division between ethnic, cultural, and racial communities within Africa which had been nurtured by colonialism and apartheid is a fact that should be confronted on all fronts. ${ }^{110}$

The duty to preserve and strengthen social and national solidarity could be anchored in both positive and negative obligations. The duty to "preserve" mainly entails an obligation not to tamper with the status quo. Even in ordinary parlance, to "preserve" is to "maintain", to "conserve" or to "safeguard". This means that the duty to preserve fits squarely within the so-called "negative duties". On the other side of the coin is the duty to "strengthen", which requires action, and is often labelled a "positive duty" in legal literature."11

As a positive duty, the child needs to promote a multi-cultural society based on dignity, humaneness, respect and so forth. These could be taken as the general values central to social and national solidarity which may form the basis of a social and national consensus in the child's community. As a negative duty, on the other hand, none of the child's activities should erode, nullify or even compromise positive aspects of any value system in society and the nation. These general statements are explained and concretized below.

As already alluded to above, four general principles underpin the African Children's Charter, one of which is non-discrimination. The right against discrimination could be a good example to assist in elaborating the child's duty to preserve social and national solidarity; this is because of its broad application, as it cannot be invoked independently, but must have regard to the range of "rights set forth in the Charter". ${ }^{112}$

As can be discerned from article 3 of the African Children's Charter, discrimination may have many perpetrators. The state, parents or guardians, and other individuals in society, may all contribute to discrimination against children. ${ }^{113}$ This last category includes the media

109 One that represents the same religion, ethnic group, culture, and so forth.

110 This does not in any way detract from the fact that individuals and communities have the right to maintain their own cultural uniqueness. This accords with an individual's freedom to organize his or her life in ways that diverge from the national standard.

111 For a discussion of positive and negative duties, see HM Malm "Between the horns of the negative-positive duty debate" (1991) 61 Philosophical Studies 187.

112 Art 3 of the African Children's Charter.

113 S Besson "The principle of non-discrimination in the Convention on the Rights of the Child" (2005) 13 Intermational Journal of Children's Rights 433 at 449. 
and other social groups, such as religious lobbies, which contribute to entrenching biases against children in social attitudes. ${ }^{114}$ However, for the purpose of this article, the most interesting are child perpetrators: children themselves being the source of discrimination against other children.

Africa represents societies with their ethnic, cultural and linguistic heterogeneity, ${ }^{115}$ a trait that sometimes proves to be a challenge for fundamental cohesion. In this context, the African child's duty to preserve social and national solidarity entails that he or she does not discriminate against other children on the basis of any of the prohibited grounds and other related criteria identified by article 3 of the African Children's Charter. It is important to stress that the right against discrimination applies irrespective of budgetary resources, ${ }^{116}$ and to each child within the state party's jurisdiction.

If the duty of the African child to preserve social and national solidarity is to be given practical applicability, discrimination against refugee children, disabled children, the girl child, minority children and so forth by other children could violate this provision. Discrimination perpetrated by children against children, be it overt or covert, offends the human dignity of the discriminated child, and is capable of undermining or even destroying social and national solidarity.

As a positive duty, viewed from the angle of post-conflict situations, the duty to strengthen social and national solidarity could entail that the child take part, for instance, in truth and reconciliation as well as traditional conflict resolution fora. Experience from countries such as Sierra Leone and Rwanda is instructive in this regard. ${ }^{117}$ However, again, the best interests of the child, as well as the evolving "capacity of the child" principle, should be the main criteria against which to assess the participation of children in these fora.

With regard to the post-conflict scenario, present day experiences in Africa (and elsewhere) show that peacemaking does more than end war; it lays the normative ground for transition and sets the agenda for peacetime. ${ }^{118}$ The

114 Ibid.

115 Contrary to what Mutua "The Banjul Charter", above at note 46 at 347, argues in the milieu of pre-colonial Africa.

116 Both the UN Committee on Economic, Social and Cultural Rights and the UN Committee on the Elimination of Discrimination against Women have highlighted that the attainment of the principle of non-discrimination is not subject to progressive realization.

117 See, for instance, UNICEF "Children and the Truth and Reconciliation Commission in Sierra Leone" (2001), available at: <http://www.unicef.org/emerg/files/SierraLeoneTRCReport.pdf $>$ (last accessed 3 October 2007).

118 I Cohn "The protection of children in peacemaking and peacekeeping processes" (1999) 12 Harvard Human Rights Journal 129 at 131 . This is because peace processes have sometimes performed as constitutional conferences in which key actors strive to define the political, social and economic framework for a new social and legal order. Peacemakers do not adequately address children's needs for several reasons: lack of awareness of the nature and extent of the impact of conflict on children; ineffective lobbying by child welfare advocates; and lack of access to information on childconscious policies and programmes that should be adapted or avoided in light of experiences in other contexts. 
international community, states and institutions, local civil society and international nongovernmental organizations come together in peace processes to determine how post-conflict society can reincorporate warriors to civilian life, facilitate resettlement of the displaced and provide for the return of refugees, advance a national agenda reconciling opposing factions and social or ethnic groups, allocate resources for development, ensure equal access to justice, and remedy past injustices. In the majority of cases, if not in all, this is an exercise necessary for re-establishing (preserving) social and national solidarity, in which children should play a vital role.

The duty of children to undertake these activities should also be interpreted as placing a duty on the state, parents or guardians, and society at large, to facilitate and assist children in fulfilling their duties. The effective accomplishment of the duty of African children to preserve and strengthen social and national solidarity might sometimes be facilitated better if children are structured and organized as, increasingly, mechanisms are being developed throughout the world to enable such participation. ${ }^{119}$ A good example is children's parliaments.

In light of the African child's duty to make a significant contribution to the political agenda and enhance social and national solidarity, decision makers should demonstrate that they are willing to listen, and to give consideration, to the proposals and issues raised by children, and act where possible. ${ }^{120}$ This guarantee would bolster children's own sense of democratic responsibility, as they would recognize that they are being taken seriously..$^{121}$

A Save the Children report, Shaping a country's future, ${ }^{122}$ provides guidelines for including young people in the formation of National Plans of Action. According to the guidelines, children must, among other things, strive to be responsible and disciplined, show respect for government officials, and respect children who speak other languages or are from backgrounds different to their own. ${ }^{123}$

Finally, there is a direct relationship between the child's duty to preserve and strengthen social and national solidarity and the right to freedom of expression, ${ }^{124}$ the right to freedom of thought, conscience and religion, ${ }^{125}$

119 Albeit often patchily and with varying degrees of effectiveness, on the one hand, and tokenism, on the other.

120 Lansdown Promoting Children's Participation, above at note 108 at 19.

121 Ibid. However, the writer also cautions against treating "the voice of young people as a panacea", for "there is plenty of evidence here that simply establishing participatory structures and opportunities for young people is no guarantee of their effectiveness".

122 Save the Children "Shaping a country's future with children and young people", available at: <http:/www.childrights.org/pahome2.0.nsf/6b9cc825455bcb7788256a730065d026/ 46d1acfac802e91088256c93007ada25/\$FIL/Summary\%20Guide\%C20for\%20Governments. doc $>$ (lastaccessed 10 October 2007).

123 Ibid

124 Art 7 of the African Children's Charter.

125 Id at art 9. 
the right to freedom of association, ${ }^{126}$ and the right of access to information. Article 11 of the African Children's Charter on the right to education is also very important. States parties to the African Children's Charter should protect, promote and fulfil these and other related rights in order to allow children to undertake their duty efficiently.

\section{The duty of the child to preserve and strengthen African cultural values in his relations with other members of the society, in the spirit of tolerance, dialogue and consultation and to contribute to the moral well-being of society}

Preservation and strengthening of African cultural values in relations with other members of the society

A harmonious reading of the first part of this statement, consistent with the provisions of the African Children's Charter generally, would require understanding that what is being sought is not the preservation of African cultural values in fossilized form, or in contradistinction to other rights, such as freedom from being subjected to harmful cultural and social practices, but the promotion of the child's positive relations with other members of society. The first goal, of course, is the integration of the child into the polity as a well-functioning member of society, able to contribute to the social capital necessary to ensure a peaceful and productive society. The value of building social capital amongst youth from an early age is selfevident. Social capital entails the production of a shared belief in the "good" attaching to citizenship, the "value added" being found in belonging and contributing. Its antithesis is pursuit of naked self-interest, trampling upon the rights of others, wanton violence or the destruction of community assets (such as the environment) for one's own gain.

Hence, the preservation and strengthening of African cultural values in day to day dealings with the elements of his society, requires that the child should give as well as take. $\mathrm{He} /$ she should be provided with benefits (such as education), as well as benefiting from and using to the optimum the opportunities provided, in a spirit of reciprocity, so as to counter individualism and egocentrism, which are decidedly "un-African", at least in theory. As Mutua notes, in the context of the "mother charter", the ACHPR, "by rejecting the egotistical individual whose only concern is fulfilling self, article $27(2)$ raises the level of care owed to neighbours and the community", 127 thereby creating the social cohesion required for viability.

The reading of this phrase that we propose does not, therefore, open the way to justify harmful cultural practices, such as female genital mutilation, debt bondage and servitude, or hazardous child labour. Our interpretation, that the African cultural practices referred to in the first part of article 31(d)

126 Id at art 8.

127 Mutua "The Banjul Charter", above at note 46 at 369 . 
concern the communitarian facets of social life in the African context, is reinforced by the second part of that article, which we consider next.

\section{Spirit of tolerance, dialogue and consultation}

The phrase "tolerance, dialogue and consultation" in the second part of article 31 (d) gives a clue to the cultural values that are probably envisaged. "Tolerance" speaks to accommodation of difference and non-discrimination. "Dialogue" refers to non-confrontational discussion, and "consultation" necessarily implies participation, rather than exclusion. These are precisely the kind of peaceable, participative and constructive approaches to problem solving, dispute resolution and community organization that characterized pre-colonial African societies. So, for instance, restorative justice is being reintroduced and fostered in many emerging child justice systems in Africa, as a participative way of redressing the harm caused by youth offending. This is on the premise that dialogue about the causes of the incident between child, victim and elders has echoes in traditional practice. ${ }^{128}$ Restorative justice not only proceeds from a philosophical premise rooted in communitarianism and ubuntu, but as a dispute resolution process also entails the child assuming responsibility for his or her misdeeds, with the support of families, extended kin and the broader community. Furthermore, seen against the backdrop of war, conflict and strife that have prevailed (and continue to do so) in Africa, the promotion and fostering of non-bellicose, non-aggressive and non-prejudiced relationships between children themselves, and between them and their societies, can only be regarded as a highly beneficial and valuable addition to the human rights agenda.

\section{Contribution to the moral well-being of society}

The child's duty to contribute to the moral well-being of society could be viewed as vague. Furthermore, it could point to a conservative agenda, one not in keeping with the modern era, its technologies and its risks (not the least of which is HIV/Aids). It could rightly be questioned whether children can be expected to shoulder the custodianship of society's moral well-being, when they themselves are supposed to be educated in order to develop sound moral values when they in turn grow up. A further question that may be controversial is, what exactly is meant by the "moral well-being of society", the content of which may mean very different things to people from different religions, cultures, backgrounds and so forth.

Two points, however, must be made. First, the moral well-being of society must be "read off" the background established by the African Children's Charter and the African Charter. In other words, it is not about this or that moral value system, but about a morality that results in societal well-being:

128 See A Skelton "The influence of the theory and practice of restorative justice in South Africa with special reference to child justice" (unpublished LLD thesis, University of Pretoria, 2005). 
peace, solidarity, non-discrimination, respect, and promotion of equality and dignity. Hence this provision does not speak to one specific moral value system, or to "the moral high ground" of one or another belief system, but rather to the elements that combine to constitute a moral society for all, one in which violence is abhorred, constitutional democracy respected, concern for the human rights and dignity of fellow human beings evidenced, and egalitarian economic regimes advanced.

Secondly, it cannot be thought that children alone bear responsibility for society's moral well-being, as this duty rests on adults too, in accordance with the ACHPR. Thus the suggestion that this duty is inappropriately placed upon children cannot be sustained.

\section{The duty of the child to preserve and strengthen the independence and the integrity of his country}

The African Children's Charter requires the child to preserve and strengthen the independence and the integrity of his country. ${ }^{129}$ of course there is a wide range of "dos and don'ts" that reinforce this provision. To start with, a fitting question in this regard is: "what are those acts that a child should not do which can negatively affect the independence and integrity of his country?" The answer to this question could be long, but we attempt below to provide some "classical" examples.

There is no need for a reminder that the child is a member of society, a civic participant. So, just like every other individual/group member in a society, the child has the duty not to commit offences against his or her country, such as treason, or any offences against the constitutional order, which are often regarded as public offences, or crimes against the public dimension of the community or state. In the context of contemporary political and social issues, the "war on terror" springs to mind: every child will have the duty not to advocate fanaticism, tribalism, social or ethnic tension, racism, or xenophobia, under the guise of exercising his/her freedom of expression, which can compromise the integrity of his/her country.

The duty to "strengthen" the independence and integrity of his/her country, however, indicates a "positive obligation", which requires the child to act in a certain manner. In this context, it is important to recount briefly the significant contribution which children have made to the liberation struggle against colonialism in a number of African countries. The struggle of South African children to end apartheid is an example worthy of particular mention. ${ }^{130}$

129 Art 31(e) of the African Children's Charter.

130 The Day of the African Child marks a 1976 march in Soweto, South Africa, when thousands of black school children took to the streets to protest against the inferior quality of their education and to demand their right to be taught in their own language. Hundreds of young boys and girls were shot at; in the two weeks of protest that followed, more than a hundred people were killed and more than a thousand were injured. 15 years later, in 1991, the OAU immortalized the Soweto Uprising by declaring 16 June the Day of the African Child. This declaration marked an official recognition of the children's contribution to the struggle against apartheid. 
A word of caution, however, is apposite at this juncture. This provision cannot be read as permitting children to become soldiers in order to promote the independence and integrity of their country. Such an interpretation would be a cynical misreading of the African Children's Charter, especially since article 22 unequivocally addresses the prohibition on the use of children as soldiers. ${ }^{131}$ As states parties have the obligation to "ensure" that children (by definition persons below the age of 18) do not take direct part in hostilities, there is no room for an interpretation which would allow children to become soldiers to fight for the independence and integrity of their country.

It is also important to mention that promoting independence and integrity of one's country does not necessarily call for an armed struggle. In fact, African values, such as negotiation and compromise, dictate that armed struggle be a measure of last resort. If the duty to "... preserve and strengthen African cultural values in his relations with other members of the society, in the spirit of tolerance, dialogue and consultation and to contribute to the moral well-being of society"132 means anything at all, confrontational mechanisms, particularly armed struggle, should be avoided by the African child as much as possible.

\section{The duty of the child to contribute to the best of his abilities at all times and at all levels, to the promotion and achievement of African unity}

Before an attempt is made to chart what is meant by the duty of the child "to contribute to the best of his abilities, at all times and at all levels, to the promotion and achievement of African unity",133 the historical background to the African Children's Charter should be briefly mentioned. The drafting of the African Children's Charter took place in the late 1980s when a number of African countries were still not independent. ${ }^{134}$ It is also important to remember that the charter was drafted under the aegis of the now defunct Organization of African Unity (OAU). One of the main objectives of the OAU was "to promote the unity and solidarity of the African States". 135 Therefore it was at the time fair to include a duty on the part of the child to promote African unity.

The fact that the duty "to contribute ... to the promotion and achievement of African unity" under the African Children's Charter traces its background mainly from the objective of the OAU does not mean that the objective is obsolete for present day Africa. As a matter of fact, the Constitutive Act which established the African Union reiterates, as one of its

131 Art 22(2) reads: "States Parties to the present Charter shall take all necessary measures to ensure that no child shall take a direct part in hostilities and refrain in particular, from recruiting any child."

132 Art 31(d) of the African Children's Charter.

133 Id at art 31 (f).

134 In 1989, countries such as Namibia and South Africa were still not independent.

135 Art II of the African Children's Charter. 
objectives, the achievement of "... greater unity and solidarity between the African countries and the peoples of Africa". ${ }^{136}$

A close reading of article 31(f) of the African Children's Charter leads one to observe that ${ }^{137}$ the child has the duty to contribute only to the "best of his abilities". This is mainly a reiteration of the limitation contained in the general preambular part of article 31 . However, what should be noteworthy is that the child has the duty to contribute "at all times and at all levels".

An evaluation of the phrase "at all levels", in particular, is very interesting and has the great potential to advance the participation rights of children. Accordingly, by taking stock of current political issues in Africa, such as the "Grand Debate on the Union Government" by the Assembly of Heads of State and Government of the African Union, children should be allowed to assume their duty and contribute, to the best of their abilities, to the debate. Depending on the "best of their abilities", children might be called upon to contribute to the work of the Pan-African Parliament, the New Partnership for Africa's Development and other similar initiatives within the continent which are ultimately tailored to promote and achieve African unity. The role, or one could say the duty, of children in the subregional social, economic and political integration process is also worthy of mention.

\section{CONCLUSION}

It was in order to give the CRC specific application in the African context that the OAU adopted the African Children's Charter, the first regional treaty on the human rights of the child. The African Children's Charter not only reflects an African normative consensus on children's rights, but also represents an attempt to Africanize, and place within the African cultural context, the children's rights discourse. That is principally why it provides for the responsibilities of children to their parents, communities and society as a whole, relative to their age and ability.

In connection with this, it may also be important to note that the duties of the child under article 31 are placed as the final substantive provision of the African Children's Charter. It seems that the drafters did this consciously, ${ }^{138}$ to underline the point that responsibilities are complementary to rights, rather than undermining them. We should conclude that the drafters did not intend governments to make the enjoyment of human rights dependent on the fulfilment of duties, but rather saw duties as the balancing elements to reinforce rights.

136 Art 3(a) of the Constitutive Act of the African Union.

137 In addition to the limitations provided by the preambular part of the provision ("age and ability, and such limitations as may be contained in the present Charter").

138 Personal communication from W Njuguna, deputy director, African Network for the Prevention and Protection against Child Abuse and Neglect, which had a key role in assisting with the drafting of the African Children's Charter. 
We have argued that, despite the African Children's Charter's recognition of duties on the part of children, it does not lose sight of its initial recognition that "... the child, due to the needs of his physical and mental development requires particular care with regard to health, physical, mental, moral and social development and requires legal protection in conditions of freedom, dignity and security". ${ }^{139}$ We have suggested, too, that the internal limitations under article 31 are tailored carefully to make it impossible for anyone to demand that the child undertake his or her duties in a way that violates his or her other rights under the charter. As we have attempted to illustrate, the charter has to be viewed not as a compendium of discrete provisions, but as an integrated document with enumerated rights (and responsibilities) being viewed both as interdependent, and as determinant of their scope and normative content. In support of this position, article 31 of the Vienna Convention on the Law of Treaties entrenches that "a treaty shall be interpreted in good faith ... in the light of its object and purpose" (emphasis added). Since the object and purpose of the African Children's Charter is the advancement of the rights of the African child, the language of duties should not be used to limit or violate children's rights.

In conclusion, we have argued that critics who have suggested that the provisions of the African Children's Charter detailing the responsibility of the child are redundant, vague, open to misinterpretation, or provide a licence for harmful practices which violate children's rights, have misconceived both the spirit and intention of the drafters, as well as the actual text of the provisions. We have suggested, by contrast, that article 31 represents a valuable addition to the international human rights agenda, and that a purposive interpretation of its constituent parts reveals that children should be required to play a role at family, community, national and continental levels, in accordance with their age and maturity as they grow up, as part and parcel of their heritage, empowerment and developing citizenship.

If the language of duties is to be accorded its rightful place in the children's rights lexicon, article 31 , and the ideals that it envisages, must be situated within a positive developmental context that aims to nurture child participation, cherish communitarian traditions, further peace-building and harmonious social development, as well as foster African unity.

Our vision is of the ideal of the dutiful child: a girl or boy who is conscious of his or her place in the community in which he or she is being raised, who is socially concerned, with a strong sense of morality and justice, and who strives to use, to the best of his or her abilities, the opportunities that arise. Our child is proud of his or her culture, but at the same time respectful of the culture of others. He or she has a natural respect for those who gave him or her life, and is keen to make a contribution not only to his or her own growth and development, but also

139 Para 6 of the preamble to the African Children's Charter. 
to the family and the community at large. Finally, in the bigger scheme, our African child is committed to observing civic responsibilities, and to participating in the unity and development of his or her nation and continent. 